\title{
Thyroid Ultrasound Features and Risk of Carcinoma: A Systematic Review and Meta-Analysis of Observational Studies
}

\author{
Luciana Reck Remonti, ${ }^{1}$ Caroline Kaercher Kramer, ${ }^{2}$ Cristiane Bauermann Leitão, ${ }^{3}$ \\ Lana Catani F. Pinto, ${ }^{4}$ and Jorge Luiz Gross ${ }^{3}$
}

Background: Thyroid nodules are a common finding in the general population, and their detection is increasing with the widespread use of ultrasound (US). Thyroid cancer is found in 5-15\% of cases depending on sex, age, and exposure to other risk factors. Some US parameters have been associated with increased risk of malignancy. However, no characteristic seems sufficiently reliable in isolation to diagnose malignancy. The objective of this meta-analysis was to evaluate the diagnostic performance of US features for thyroid malignancy in patients with unselected thyroid nodules and nodules with indeterminate fine-needle aspiration (FNA) cytology.

Methods: Electronic databases were reviewed for studies published prior to July 2012 that evaluated US features of thyroid nodules and reported postoperative histopathologic diagnosis. A manual search of references of review and key articles, and previous meta-analyses was also performed. A separate meta-analysis was performed including only nodules with indeterminate cytology. Analyzed features were solid structure, hypoechogenicity, irregular margins, absence of halo, microcalcifications, central vascularization, solitary nodule, heterogeneity, taller than wide shape, and absence of elasticity.

Results: Fifty-two observational studies (12,786 nodules) were included. Nine studies included nodules with indeterminate cytology as a separate category, comprising 1851 nodules. In unselected nodules, all US features were significantly associated with malignancy with an odds ratio varying from 1.78 to 35.7, and microcalcifications, irregular margins, and a taller than wide shape had high specificities (Sp; 87.8\%, 83.1\%, 96.6\%) and positive likelihood ratios (LHR; 3.26, 2.99, 8.07). Absence of elasticity was the single feature with the best diagnostic performance (sensitivity $87.9 \%$, Sp $86.2 \%$, and positive LHR 6.39). The presence of central vascularization was the most specific US feature in nodules with indeterminate cytology (Sp 96\% and positive LHR 2.13).

Conclusions: US features in isolation do not provide reliable information to select nodules that should have a FNA performed. A combination of US characteristics with higher likelihood ratios and consequently with higher post-test probabilities of malignancy-microcalcifications, or a taller than wide shape, or irregular margins, or absence of elasticity - will probably identify nodules with an increased risk for malignancy. Further studies are required to standardize elastography techniques and evaluate outcomes, especially in nodules with an indeterminate cytology.

\section{Introduction}

$\mathbf{T}$ HYROID NODULES ARE A COMMON FINDING in the general population, and their detection is increasing with the widespread use of ultrasound (US). The prevalence of thyroid nodularity varies from $19 \%$ to $67 \%$, and increases with age, affecting about $50 \%$ of the population older than 40 years of age (1-5). The clinical significance of thyroid nodules relates to the need to exclude thyroid cancer, which is found in
$5-15 \%$ of cases, depending on sex, age, and exposure to other risk factors (5-8). The incidence of thyroid cancer has increased about fivefold in the last 50 years, mostly due to small papillary thyroid cancers, the most indolent form of thyroid cancer (9).

Some US parameters, such as microcalcifications, hypoechogenicity, absence of a halo, increased intranodular vascularity, nodule shape or irregular margins, have been traditionally associated with increased risk of malignancies

\footnotetext{
${ }^{1}$ Division of Endocrinology, Hospital de Clínicas de Porto Alegre, Porto Alegre, Brazil.

${ }^{2}$ Division of Endocrinology, University of Toronto, Toronto, Canada.

Departments of ${ }^{3}$ Internal Medicine and ${ }^{4}$ Endocrinology, Universidade Federal do Rio Grande do Sul, Porto Alegre, Brazil.
}

(C) Luciana Reck Remonti et al. 2015; Published by Mary Ann Liebert, Inc. This Open Access article is distributed under the terms of the Creative Commons Attribution Noncommercial License (http://creativecommons.org/licenses/by-nc/4.0/) which permits any noncommercial use, distribution, and reproduction in any medium, provided the original author(s) and the source are credited. 
(10). However, none of these characteristics seems sufficiently reliable in isolation to diagnose malignancy. Diagnostic sensitivity ranges from $26.5 \%$ to $87.1 \%$ for hypoechogenicity, $54.3 \%$ to $74.3 \%$ for intranodular vascularity, and $26.1 \%$ to $59.1 \%$ for microcalcifications, whereas specificity ranges from $43.4 \%$ to $94.3 \%, 78.6 \%$ to $80.8 \%$, and $85.8 \%$ to $95 \%$, respectively $(4,10,11)$. More recently, US determination of tissue elasticity (elastography) has been suggested to detect malignancy in thyroid nodules. A meta-analysis found a sensitivity of $92 \%$ and specificity of $90 \%$ using this technique. However, only a few studies were included, and only three used histopathology of surgical specimens for final diagnosis (12). Fineneedle aspiration (FNA) biopsy is considered the most accurate procedure to identify malignant nodules. To implement biopsies in all patients harboring a thyroid nodule is too burdensome, and the results of FNA have some limitations. The indications are broad and vague, and usually include patients with a family history of thyroid cancer, or those who have had significant radiation exposure, or those who have a combination of suspicious US features $(5,10)$. However, there is no information about the probability of the US features associated with malignancy and which combination would be more clinically useful. US features may be also useful in clinical decision making for patients with FNA specimens insufficient for diagnosis (10\%) or where specimens are indeterminate $(15-30 \%)$, the latter carrying a $20-30 \%$ risk of malignancy $(4,5)$. A recent metaanalysis evaluating the accuracy of US to predict malignancy in thyroid nodules found sensitivities ranging from $26 \%$ to $87 \%$, and specificities from $40 \%$ to $93 \%$. In this study, a taller than wide shape showed the highest diagnostic odds ratio (OR) for cancer. However, that metaanalysis included studies that used cytology, instead of histology, as a final diagnosis for benign nodules. Besides, it did not evaluate the accuracy of elastography to predict malignancy (13). Moreover, there was no description of the probability-likelihood ratio-of US characteristics associated with malignancy. The likelihood ratio would provide more information to be used in the clinical decision making of thyroid nodules than just sensitivity and specificity (14).

The aim of this study was to conduct a systematic review and meta-analysis of observational studies evaluating the diagnostic performance of US features considered to be associated with thyroid malignancy in patients with unselected thyroid nodules or nodules with indeterminate FNA cytology, considering only histopathologic diagnosis of surgical specimens as the final diagnosis.

\section{Material and Methods}

\section{Search strategy}

MEDLINE was searched using the following medical subject heading terms: "Thyroid Nodule" [MeSH] AND ("Ultrasonography" [MeSH] OR "ultrasonography" [Subheading] OR "Ultrasonography, Doppler"[MeSH]). EMBASE was searched using EmTree terms "Thyroid nodule" and "Ultrasonography." The search period ended in July 2012. A manual search of the references of review articles, previous metaanalyses, and key articles was also performed. All potentially eligible studies were considered for review regardless of the primary outcome or language.

\section{Study selection}

Observational studies of patients with thyroid nodules evaluated by US and submitted to thyroidectomy regardless of the reason for surgery were considered for inclusion. Only studies with histopathologic diagnosis of surgical specimens were considered. Two independent investigators (L.R.R. and C.K.K.) selected potentially eligible studies based on titles and abstracts. All the studies selected were retrieved for full-text evaluation. Disagreements were solved by a third investigator (C.B.L.).

\section{Data extraction and quality assessment}

Two investigators reviewed the selected studies for patient characteristics, US features, and histopathologic results. Any discrepancies between the data extracted were discussed until a consensus was reached. The absolute number of patients with and without the evaluated features and with and without malignancy was extracted. These data were entered into a computerized spreadsheet considering true positives, true negatives, false positives, and false negatives.

The diagnostic ability to diagnose thyroid malignancy of the following US features was evaluated: solid structure, hypoechogenicity, irregular margins, absence of halo, microcalcifications, central vascularization, solitary nodule, heterogeneity, taller than wide shape, and absence of elasticity. The presence of these features was defined as described in the original study.

Two independent investigators (L.R.R. and L.C.F.P.) evaluated the quality of the included studies using the QUADAS-2 tool (15). Any disagreements were solved by a third investigator (CBL). The present meta-analysis was described according to proposed by Stroup et al. (16). Details are available in Supplementary Table S1 (Supplementary Data are available online at www.liebertpub.com/thy).

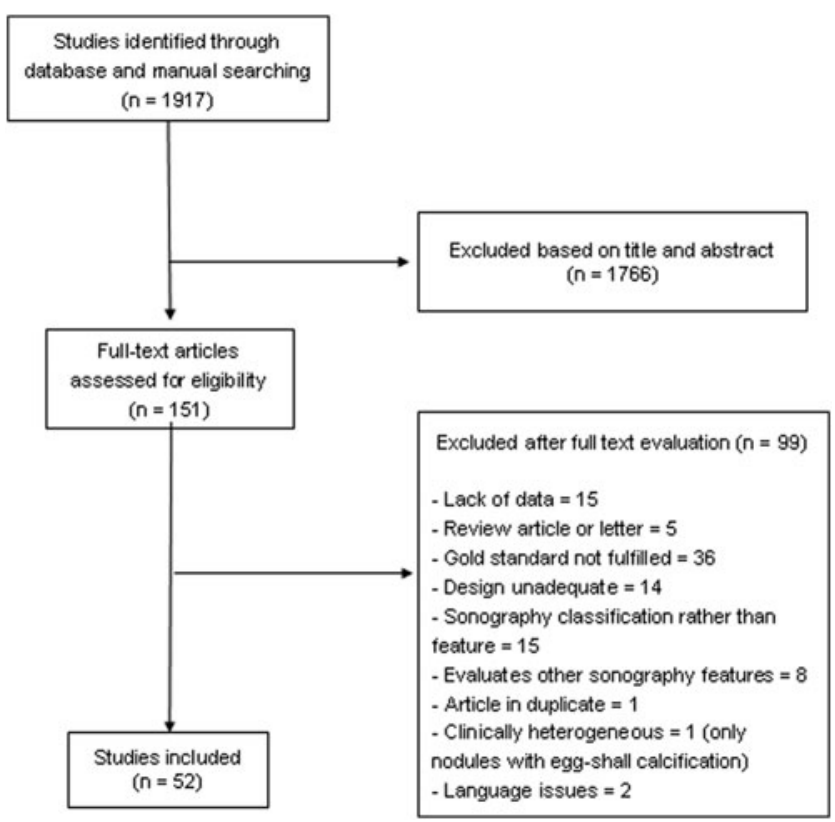

FIG. 1. Flowchart of article selection. 
Table 1. Characteristics of Studies Included in Meta-Analysis

\begin{tabular}{|c|c|c|c|c|c|c|}
\hline Author (reference) & Year & $\begin{array}{l}\text { Number of } \\
\text { nodules }\end{array}$ & $\begin{array}{c}\text { Male } \\
\text { sex }(\%)\end{array}$ & $\begin{array}{c}\text { Age } \\
\text { (mean) }\end{array}$ & Clinical background & US features evaluated \\
\hline Walker J (65) & 1985 & 94 & 14.8 & & $\begin{array}{l}\text { All patients submitted to } \\
\text { surgery }\end{array}$ & Solid \\
\hline Aggarwal S (17) & 1989 & 36 & & & Patients with cold nodules & Solid \\
\hline Cox M (29) & 1991 & 68 & 10 & 48.6 & $\begin{array}{l}\text { Patients submitted to surgery } \\
\text { with no compressive } \\
\text { symptoms or obvious } \\
\text { malignancy }\end{array}$ & Solitary, solid \\
\hline Hübsch V (36) & 1992 & 65 & 30 & 42 & $\begin{array}{l}\text { Patients with cold nodules, } \\
\text { compressive symptoms, } \\
\text { hyperthyroidism, or } \\
\text { malignancy suspected or } \\
\text { confirmed }\end{array}$ & $\begin{array}{l}\text { Hypoechogenicity, } \\
\text { microcalcifications, central } \\
\text { vascularization, solitary, } \\
\text { solid, heterogeneity, and } \\
\text { irregular margins }\end{array}$ \\
\hline Brkljacic B (21) & 1994 & 426 & 13.3 & 46.5 & $\begin{array}{l}\text { Patients with multinodular } \\
\text { goiter }\end{array}$ & $\begin{array}{l}\text { Hypoechogenicity, } \\
\text { microcalcifications }\end{array}$ \\
\hline Ousehal A (46) & 1996 & 100 & & 39 & $\begin{array}{l}\text { Unselected patients submitted } \\
\text { to surgery }\end{array}$ & $\begin{array}{l}\text { Hypoechogenicity, irregular } \\
\text { margins }\end{array}$ \\
\hline Rago T (55) & 1998 & 104 & 33 & 42.3 & $\begin{array}{l}\text { Patients with single nodule } \\
\text { with compressive } \\
\text { symptoms or suspicion of } \\
\text { malignancy }\end{array}$ & $\begin{array}{l}\text { Hypoechogenicity, absence of } \\
\text { halo, microcalcifications }\end{array}$ \\
\hline Kakkos S (37) & 2000 & 188 & & & $\begin{array}{l}\text { All patients submitted to } \\
\text { surgery }\end{array}$ & Microcalcifications \\
\hline Bozbora A (20) & 2002 & 81 & 25 & 33 & $\begin{array}{l}\text { Patients with cold solitary or } \\
\text { dominant nodule }\end{array}$ & Solitary \\
\hline Giammanco M (33) & 2002 & 125 & 21.6 & 57 & $\begin{array}{l}\text { All patients submitted to } \\
\text { surgery }\end{array}$ & Central vascularization \\
\hline Khoo M (38) & 2002 & 361 & & & $\begin{array}{l}\text { Consecutive patients } \\
\text { submitted to surgery }\end{array}$ & Microcalcifications \\
\hline Kountakis S (40) & 2002 & 83 & & & $\begin{array}{l}\text { All patients submitted to } \\
\text { surgery }\end{array}$ & Solitary \\
\hline Leenhardt L (41) & 2002 & 155 & 25.1 & & $\begin{array}{l}\text { Patients submitted to surgery } \\
\text { with no hormonal } \\
\text { dysfunction }\end{array}$ & $\begin{array}{l}\text { Hypoechogenicity, } \\
\text { microcalcifications, solid, } \\
\text { irregular margins }\end{array}$ \\
\hline Peccin S (47) & 2002 & 80 & 20 & 45.3 & $\begin{array}{l}\text { Patients with compressive } \\
\text { symptoms or suspicion of } \\
\text { malignancy }\end{array}$ & $\begin{array}{l}\text { Hypoechogenicity, absence } \\
\text { of halo, microcalcifications }\end{array}$ \\
\hline Casella C (25) & 2003 & 66 & 15.1 & 44.6 & Patients submitted to surgery & Central vascularization \\
\hline Alexopoulou O (18) & 2004 & 109 & & & $\begin{array}{l}\text { Patients with nontoxic } \\
\text { multinodular goiter }\end{array}$ & $\begin{array}{l}\text { Hypoechogenicity, } \\
\text { microcalcifications }\end{array}$ \\
\hline Fukunari N (31) & 2004 & 310 & 14.19 & 47 & $\begin{array}{l}\text { Patients with cold solitary } \\
\text { nodules }\end{array}$ & Central vascularization \\
\hline Penfold A (48) & 2004 & 83 & 13.2 & & Patients submitted to surgery & $\begin{array}{l}\text { Hypoechogenicity, absence of } \\
\text { halo, microcalcifications, } \\
\text { central vascularization, } \\
\text { irregular margins }\end{array}$ \\
\hline Seiberling K (59) & 2004 & 159 & 23.2 & 46 & Patients submitted to surgery & Microcalcifications \\
\hline Kobayashi K (39) & 2005 & 910 & & 49 & $\begin{array}{l}\text { Patients submitted to surgery } \\
\text { with diagnosis of follicular } \\
\text { nodule }\end{array}$ & $\begin{array}{l}\text { Solitary, solid, irregular } \\
\text { margins }\end{array}$ \\
\hline Nicola H (30) & 2005 & 86 & & & $\begin{array}{l}\text { Patients with follicular } \\
\text { neoplasms on FNA }\end{array}$ & Central vascularization \\
\hline Popowicz B (51) & 2006 & 356 & & & Patients submitted to surgery & Microcalcifications, solitary \\
\hline Sahin M (56) & 2006 & 472 & 17.8 & 51.5 & Patients submitted to surgery & $\begin{array}{l}\text { Hypoechogenicity, absence of } \\
\text { halo, microcalcifications, } \\
\text { solid, heterogeneity, } \\
\text { irregular margins }\end{array}$ \\
\hline Wang N (66) & 2006 & 322 & 18.4 & 44 & Patients submitted to surgery & Microcalcifications \\
\hline Cappelli C (24) & 2006 & 349 & & & $\begin{array}{l}\text { Nodules with malignant or } \\
\text { suspicious cytology }\end{array}$ & $\begin{array}{l}\text { Hypoechogenicity, } \\
\text { microcalcifications, central } \\
\text { vascularization, irregular } \\
\text { margins }\end{array}$ \\
\hline
\end{tabular}


Table 1. (Continued)

\begin{tabular}{|c|c|c|c|c|c|c|}
\hline Author (reference) & Year & $\begin{array}{l}\text { Number of } \\
\text { nodules }\end{array}$ & $\begin{array}{l}\text { Male } \\
\text { sex }(\%)\end{array}$ & $\begin{array}{c}\text { Age } \\
\text { (mean) }\end{array}$ & Clinical background & US features evaluated \\
\hline Rago T (52) & 2007 & 505 & 21.18 & 45 & $\begin{array}{l}\text { Cold nodules with cytological } \\
\text { diagnosis of follicular or } \\
\text { Hürthle cell lesion }\end{array}$ & $\begin{array}{l}\text { Hypoechogenicity, } \\
\text { microcalcifications, } \\
\text { irregular margins }\end{array}$ \\
\hline Rago T (53) & 2007 & 92 & 31.52 & 41.6 & $\begin{array}{l}\text { Patients submitted to surgery } \\
\text { for compressive symptoms } \\
\text { or FNA suspicious }\end{array}$ & $\begin{array}{l}\text { Hypoechogenicity, absence of } \\
\text { halo, microcalcifications, } \\
\text { central vascularization, } \\
\text { elasticity }\end{array}$ \\
\hline Sharma R (60) & 2007 & 52 & 26.9 & & $\begin{array}{l}\text { Patients with cold solitary } \\
\text { nodules }\end{array}$ & Central vascularization \\
\hline Sippel R (63) & 2007 & 325 & 18.5 & 47 & $\begin{array}{l}\text { Patient with FNA diagnosis } \\
\text { of follicular or Hürthle cell } \\
\text { neoplasm or indeterminate }\end{array}$ & $\begin{array}{l}\text { Hypochogenicity, central } \\
\text { vascularization, solid, } \\
\text { heterogeneity }\end{array}$ \\
\hline Varverakis E (64) & 2007 & 85 & 20 & & $\begin{array}{l}\text { Patients submitted to surgery } \\
\text { due to risk of malignancy } \\
\text { or compressive symptoms }\end{array}$ & Central vascularization \\
\hline Bakhshaee M (19) & 2008 & 85 & 13 & 36.88 & $\begin{array}{l}\text { Patients submitted to surgery } \\
\text { due to FNA diagnosis or } \\
\text { obstructive or cosmetic } \\
\text { reasons }\end{array}$ & Central vascularization, solid \\
\hline Choi Y (28) & 2008 & 175 & & & Patients submitted to surgery & $\begin{array}{l}\text { Hypoechogenicity, } \\
\text { microcalcifications, taller } \\
\text { than wide shape, solid, } \\
\text { irregular margins }\end{array}$ \\
\hline Gulcelik N (34) & 2008 & 98 & 16.32 & 46.7 & $\begin{array}{l}\text { Patients with cytology } \\
\text { reporting follicular } \\
\text { neoplasm }\end{array}$ & $\begin{array}{l}\text { Hypoechogenicity, } \\
\text { microcalcifications, } \\
\text { solitary, solid }\end{array}$ \\
\hline Salmaslioglu A (57) & 2008 & 1926 & 19 & 46.9 & $\begin{array}{l}\text { Patients with multinodular } \\
\text { goiter submitted to surgery }\end{array}$ & $\begin{array}{l}\text { Hypoechogenicity, } \\
\text { microcalcifications, solid, } \\
\text { irregular margins }\end{array}$ \\
\hline Chen G (27) & 2009 & 758 & 23 & & Patients submitted to surgery & Microcalcifications \\
\hline Hong Y (35) & 2009 & 145 & 17.7 & 46 & $\begin{array}{l}\text { Consecutive patients } \\
\text { submitted to surgery }\end{array}$ & $\begin{array}{l}\text { Hypoechogenicity, } \\
\text { microcalcifications, central } \\
\text { vascularization, elasticity, } \\
\text { taller than wide shape, } \\
\text { irregular margins }\end{array}$ \\
\hline Liu F (43) & 2009 & 40 & 7.5 & 43.7 & $\begin{array}{l}\text { Patients with lymphocytic } \\
\text { thyroiditis and nodules } \\
\text { FNA malignant or } \\
\text { indeterminate }\end{array}$ & $\begin{array}{l}\text { Hypoechogenicity, absence of } \\
\text { halo, microcalcifications, } \\
\text { irregular margins }\end{array}$ \\
\hline Mendelson A (45) & 2009 & 77 & 16.8 & & $\begin{array}{l}\text { FNA reporting follicular, } \\
\text { Hürthle cell or } \\
\text { nondiagnostic }\end{array}$ & Microcalcifications, solid \\
\hline Phuttharak W (49) & 2009 & 31 & 3.3 & 41.8 & $\begin{array}{l}\text { Patients with risk of } \\
\text { malignancy after US and } \\
\text { FNA }\end{array}$ & $\begin{array}{l}\text { Hypoechogenicity, } \\
\text { microcalcifications, central } \\
\text { vascularization, taller than } \\
\text { wide shape }\end{array}$ \\
\hline Popowicz B (50) & 2009 & 1141 & & 49.5 & Patients submitted to surgery & $\begin{array}{l}\text { Hypoechogenicity, } \\
\text { microcalcifications, central } \\
\text { vascularization, solitary, } \\
\text { taller than wide shape }\end{array}$ \\
\hline Rago T (54) & 2010 & 195 & 26.1 & 44 & $\begin{array}{l}\text { Patients with indeterminate } \\
\text { or nondiagnostic cytology }\end{array}$ & $\begin{array}{l}\text { Hypoechogenicity, absence of } \\
\text { halo, microcalcifications, } \\
\text { central vascularization, } \\
\text { elasticity }\end{array}$ \\
\hline $\begin{array}{l}\text { Schueller-Weidekamm C } \\
\text { (58) }\end{array}$ & 2010 & 31 & 31.42 & 55.2 & Patients with cold nodules & $\begin{array}{l}\text { Hypoechogenicity, } \\
\text { microcalcifications, central } \\
\text { vascularization, irregular } \\
\text { margins }\end{array}$ \\
\hline Sillery J (62) & 2010 & 102 & 35 & 53 & $\begin{array}{l}\text { Patients with diagnosis of } \\
\text { follicular carcinoma and } \\
\text { adenoma }\end{array}$ & $\begin{array}{l}\text { Hypoechogenicity, absence of } \\
\text { halo, microcalcifications, } \\
\text { central vascularization, } \\
\text { heterogeneity }\end{array}$ \\
\hline
\end{tabular}


Table 1. (CONTINUED)

\begin{tabular}{|c|c|c|c|c|c|c|}
\hline Author (reference) & Year & $\begin{array}{l}\text { Number of } \\
\text { nodules }\end{array}$ & $\begin{array}{l}\text { Male } \\
\text { sex }(\%)\end{array}$ & $\begin{array}{c}\text { Age } \\
\text { (mean) }\end{array}$ & Clinical background & US features evaluated \\
\hline Wang Y (67) & 2010 & 51 & 25.5 & 48.6 & $\begin{array}{l}\text { Patients with single nodules } \\
\text { submitted to surgery }\end{array}$ & $\begin{array}{l}\text { Microcalcifications, central } \\
\text { vascularizaion, elasticity, } \\
\text { irregular margins }\end{array}$ \\
\hline Yoon J (68) & 2010 & 99 & 13.13 & 43.71 & $\begin{array}{l}\text { Patients with indeterminate } \\
\text { cytology }\end{array}$ & $\begin{array}{l}\text { Hypoechogenicity, microcal- } \\
\text { cifications, solitary, taller } \\
\text { than wide shape, solid, } \\
\text { irregular margins }\end{array}$ \\
\hline Cakir B (22) & 2011 & 391 & 17.12 & 46.08 & $\begin{array}{l}\text { Patients with compressive } \\
\text { symptoms or malignant } \\
\text { or suspicious cytology }\end{array}$ & Elasticity \\
\hline Maia F (44) & 2011 & 143 & 15.4 & 47.2 & Patients submitted to surgery & $\begin{array}{c}\text { Hypoechogenicity, microcal- } \\
\text { cifications, central vascu- } \\
\text { larization, irregular margins }\end{array}$ \\
\hline Castro M (26) & 2011 & 462 & 53.7 & 31 & $\begin{array}{l}\text { Patients with suspicious } \\
\text { cytology }\end{array}$ & Solitary \\
\hline Ghervan (32) & 2011 & 99 & & & $\begin{array}{l}\text { Patients with suspicious } \\
\text { nodules }\end{array}$ & Elasticity \\
\hline Lippolis P (42) & 2011 & 102 & 32.3 & 46.5 & $\begin{array}{l}\text { Patients with indeterminate } \\
\text { cytology }\end{array}$ & $\begin{array}{l}\text { Hypoechogenicity, microcal- } \\
\text { cifications, central vascu- } \\
\text { larization, elasticity }\end{array}$ \\
\hline Shuzhen C (61) & 2011 & 291 & 25 & 43.38 & Patients submitted to surgery & Elasticity \\
\hline Cantisani V (23) & 2012 & 97 & 33 & 54 & $\begin{array}{l}\text { Patients submitted to surgery } \\
\text { due to compressive symp- } \\
\text { toms or suspicious nodules }\end{array}$ & $\begin{array}{l}\text { Hypoechogenicity, } \\
\text { microcalcifications, central } \\
\text { vascularization }\end{array}$ \\
\hline
\end{tabular}

US, ultrasound; FNA, fine-needle aspiration.

\section{Statistical analysis}

The overall OR was calculated to assess the predictive value of each US feature for malignancy. The Cochran chi-square and the $I^{2}$ tests were used to evaluate statistical heterogeneity among studies, and a threshold value of $p=0.10$ was considered significant. Risk estimates were obtained with a random effects meta-analysis if significant heterogeneity was found among the studies in preliminary models.

The pooled sensitivity, specificity, positive and negative likelihood ratios, and post-test probabilities (14) were calculated using a mean pretest probability of $10 \%$ based on the average of malignancy found in thyroid nodules in general (5-8). The likelihood ratio represents how many times more (or less) frequently patients with the disease present that particular result than a patient without the disease; it is a statistical means that summarizes the diagnostic accuracy of a test (14). Likelihood ratios $>10$ or $<0.1$ are considered strong evidence to, respectively, confirm or rule out the diagnosis of interest (14).

The possibility of publication bias was evaluated using a funnel plot of a trial's effect size against the SE. Funnel plot asymmetry was analyzed by the Begg and Egger tests. Trimand-fill computation was used to estimate the effect of publication bias.

A separate meta-analysis was performed including only patients with nodules with an indeterminate cytology. As FNA cytology classification has changed over time, indeterminate cytology was defined as reported in the original article including those classified as indeterminate or suspicious.

All statistical analyses were performed using Stata v11.0 software (StataCorp LP, College Station, TX).

\section{Results}

The initial search retrieved 1917 articles, of which 1766 were excluded based on title and abstract. Full-text assessment was performed on 151 articles, and of these, 52 were selected for the present study (Fig. 1). Therefore, 12,786 nodules were included in the analysis (17-68). Nine studies including patients with indeterminate cytology aspirates, comprising 1851 nodules, were included in a separate metaanalysis. The characteristics of the included studies are described in Table 1.

High statistical heterogeneity was identified in the analysis of all but two US features (heterogeneity and having a taller than wide shape); therefore, the random effects model was used. Funnel plot and the Egger test suggested a publication bias on analysis of the following US features: heterogeneity, hypoechogenicity, solidity, and central vascularization when considering all unselected nodules. However, trim-and-fill computation revealed that publication bias did not interfere with the interpretation of results.

\section{Quality of studies}

Included studies had, in general, a low risk of bias. The most concerning issue was the lack of description if the US assessor was blinded for the histopathologic diagnosis. As US has to be performed prior to surgery, the person who performed the US was not aware of the histopathologic diagnosis. It was also considered that some studies may have limitations due to patient selection, in most cases because they included only patients with cold nodules. Details about quality of trials are described in Supplementary Table S2. 
Microcalcifications

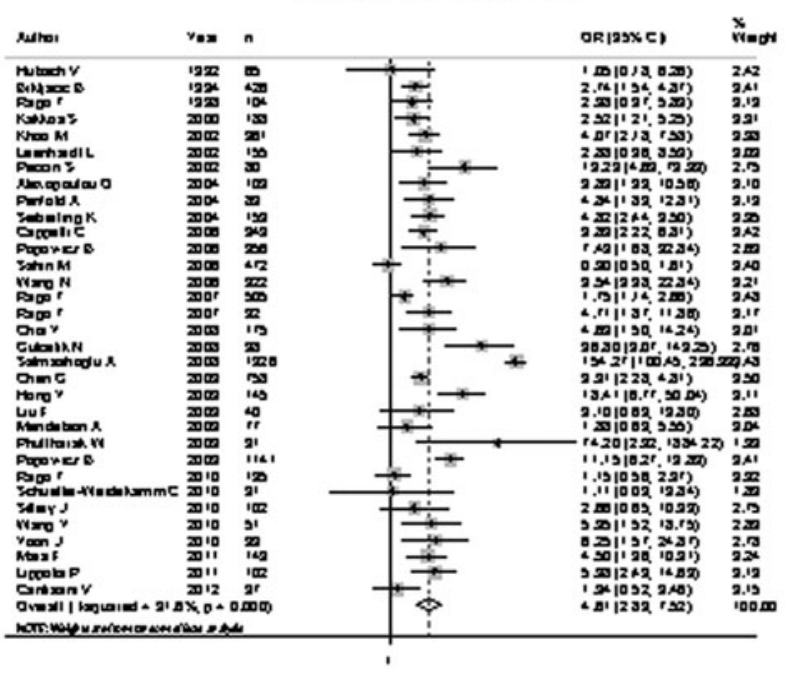

Central vascularization

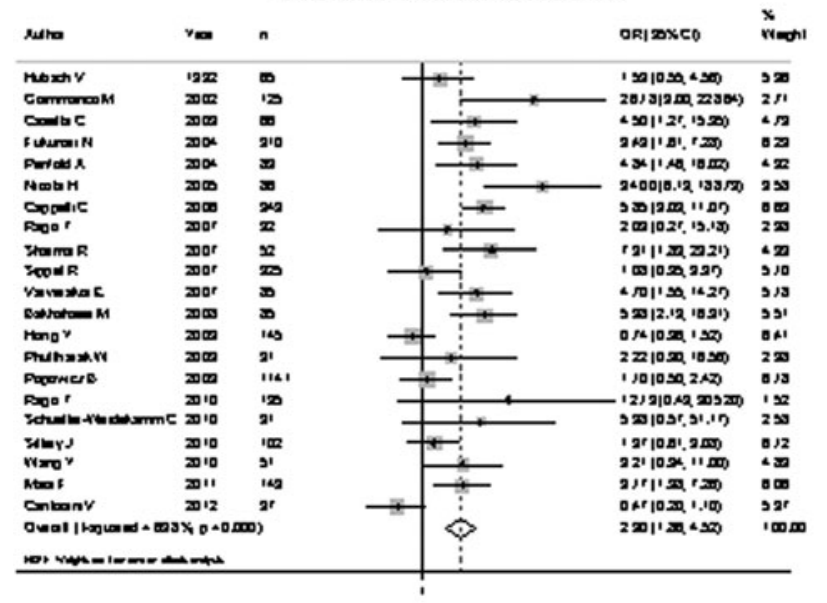

Solitary

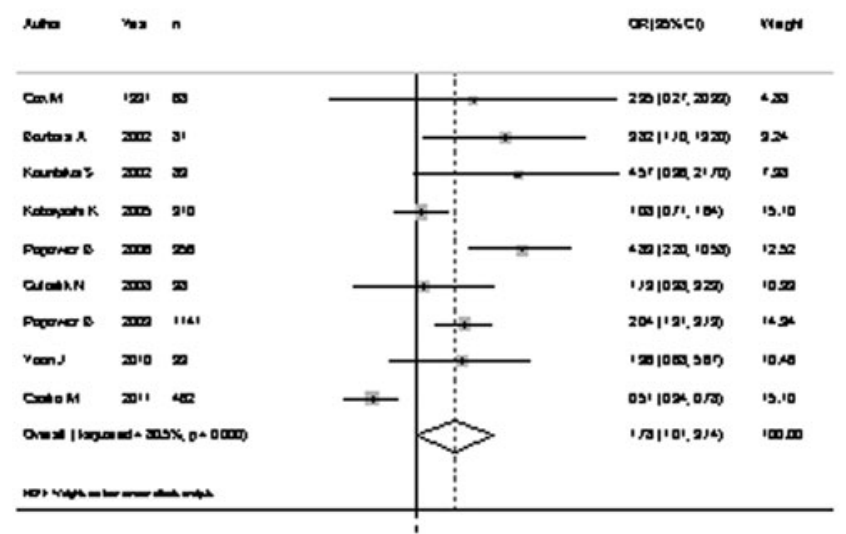

Hypoechogenicity

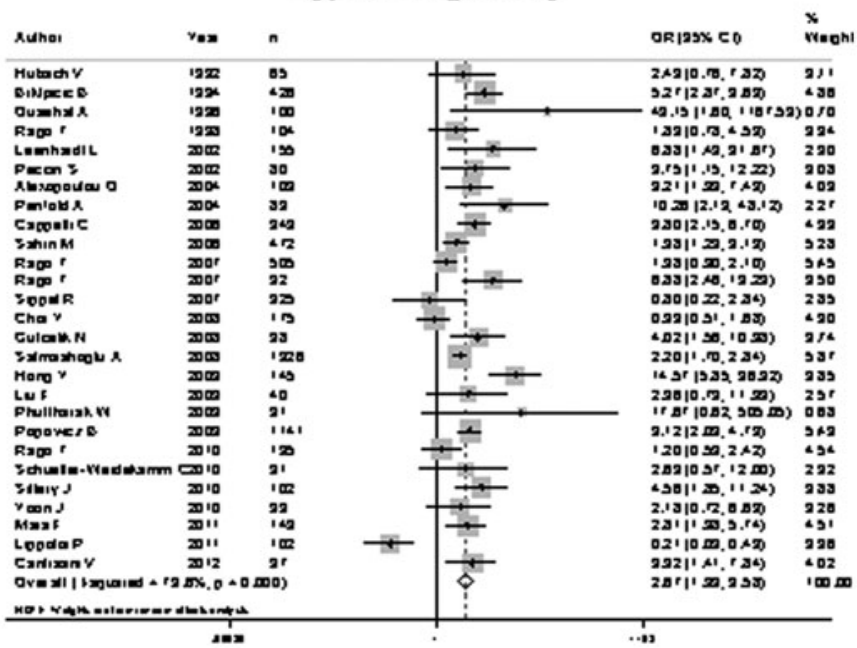

Irregular margins

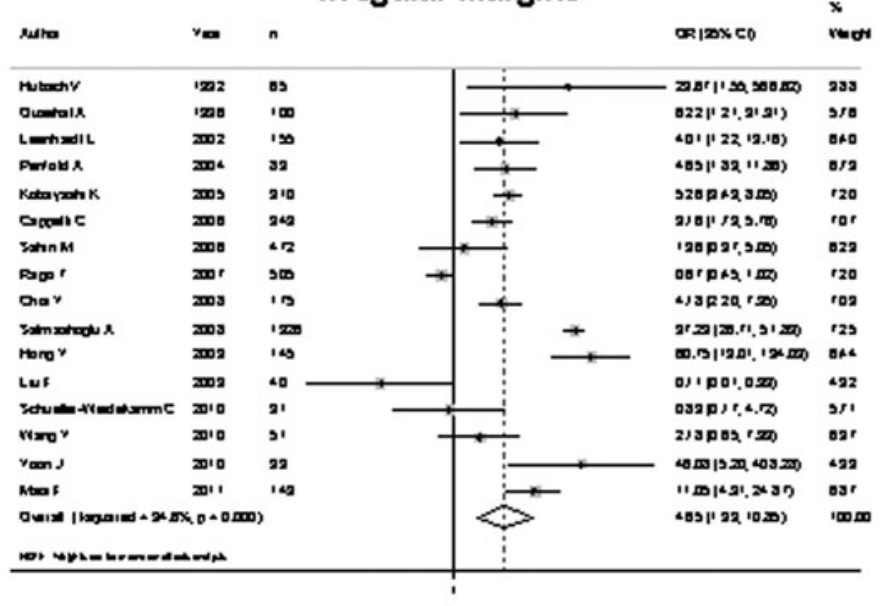

Solid

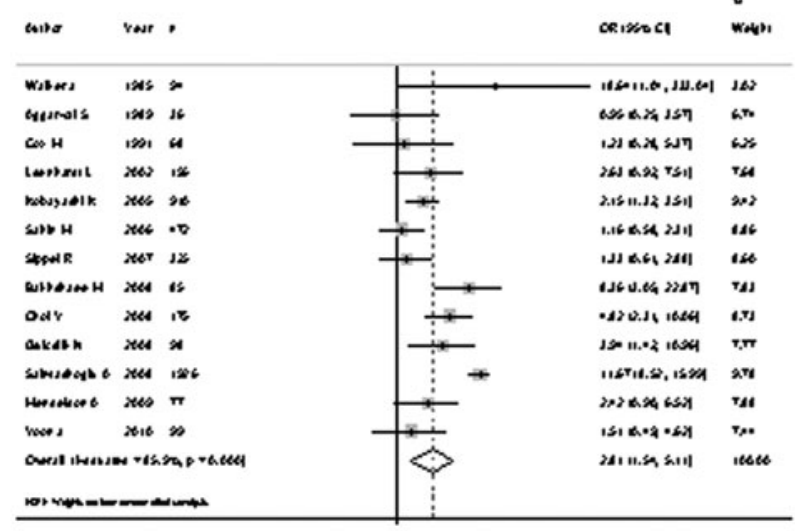

FIG. 2. Forest plot representing odds ratio (OR) for malignancy of each ultrasound (US) feature evaluated.

\section{Diagnostic performance of US features in all nodules}

All the features evaluated were significantly associated with malignancy, with an overall OR ranging from 1.77 to 35.7 (Fig. 2). However, the sensitivity of US features traditionally associated with malignancy was somewhat low, ranging from
$26.7 \%$ to $63 \%$, which means that, using these features individually, $37 \%$ to $73.3 \%$ of cancers would not be diagnosed. Four of these features-microcalcifications, central vascularization, irregular margins, and a taller than wide shapeshowed better specificity than the other features: $87.8 \%, 78 \%$, $83.1 \%$, and $96.6 \%$, respectively. The positive likelihood ratio 


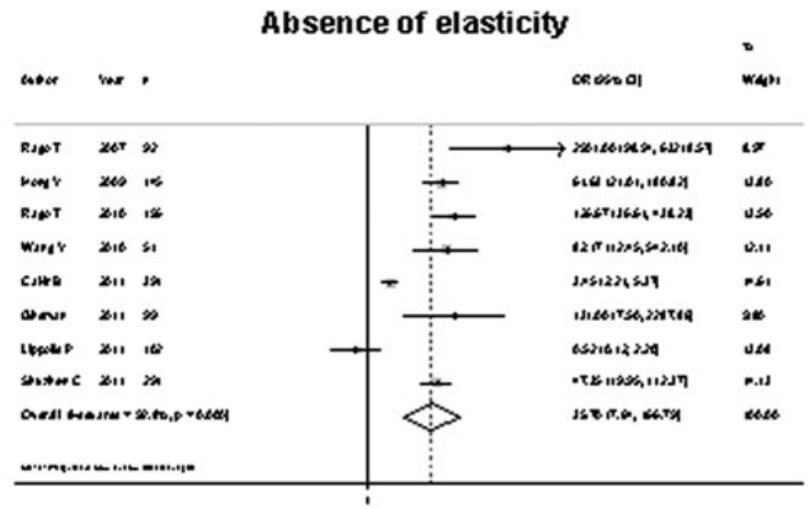

Absence of halo

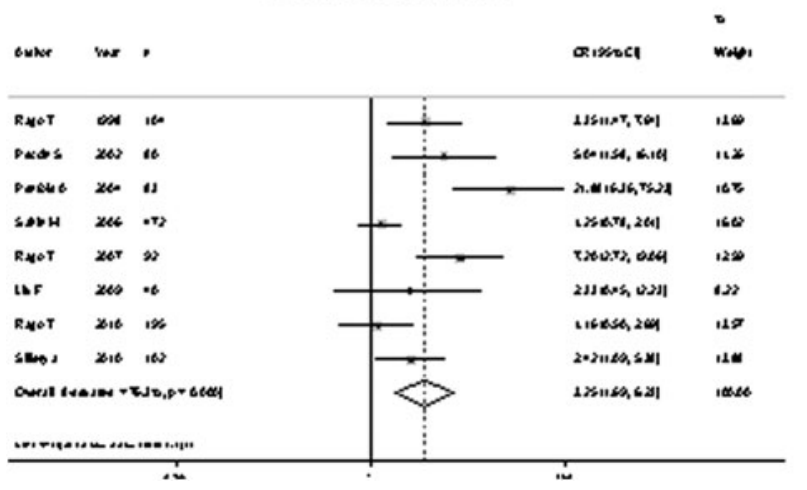

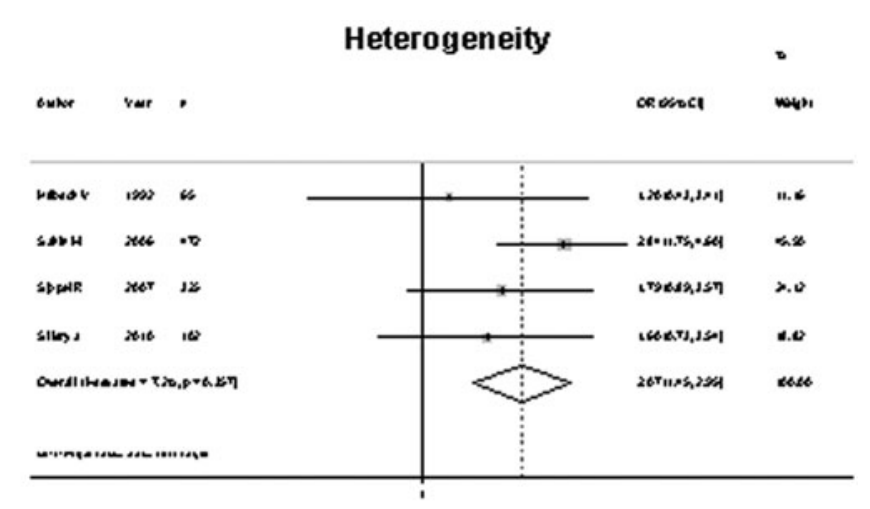

Higher than width shape

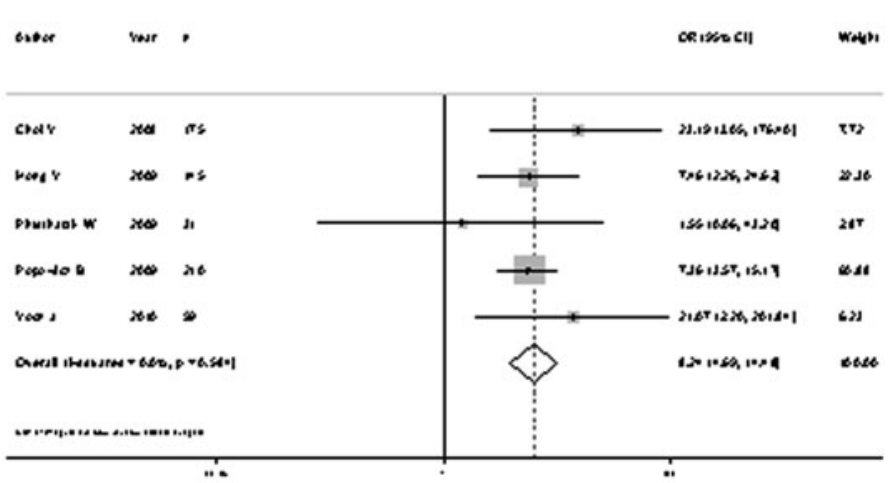

FIG. 2. (Continued).

ranged from 1.33 to 8.07 , and the negative likelihood ratio from 0.13 to 0.77 (Table 2). Considering a pretest probability of $10 \%$, the post-test probability of malignancy ranged from $12.8 \%$ to $47.0 \%$ after a positive test, and $1.4 \%$ to $7.8 \%$ with a negative test result. Absence of elasticity was the US feature that showed the best diagnostic accuracy, with a sensitivity of $87.9 \%$, a specificity of $86.2 \%$, and a positive and negative LHR of 6.39 and 0.13 , respectively (Table 2).

\section{Diagnostic performance of US features in nodules with indeterminate cytology}

Only a few of the studies reported the histopathologic diagnosis specifically for nodules with an indeterminate cy- tology. Because of that, only the following features were analyzed: absence of halo, absence of elasticity, hypoechogenicity, solid structure, presence of microcalcifications, solitary nodule, irregular margins, and central vascularization. Of these, pooled diagnostic accuracy statistics could be calculated only for hypoechogenicity, central vascularization, and presence of microcalcifications because more than three studies are needed in order to perform a meta-analysis of a diagnostic test. Only the presence of microcalcifications was significantly associated with malignancy (Fig. 3). However, in this subgroup of nodules, any of the US features was not able to determinate the risk of malignancy with an acceptable sensitivity (Table 3 ). Presence of central vascularization was the feature with the best specificity (96\%). The

Table 2. Diagnostic Performance of Each US Feature in the Differentiation of Benign and Malignant Thyroid Nodules in Unselected Nodules

\begin{tabular}{|c|c|c|c|c|c|c|}
\hline Feature & $\begin{array}{l}\text { Sensitivity } \\
(\%)\end{array}$ & $\begin{array}{c}\text { Specificity } \\
(\%)\end{array}$ & $\begin{array}{c}\text { Positive } \\
\text { likelihood ratio }\end{array}$ & $\begin{array}{c}\text { Post-test } \\
\text { probability }(\%)^{\mathrm{a}}\end{array}$ & $\begin{array}{c}\text { Negative } \\
\text { likelihood ratio }\end{array}$ & $\begin{array}{c}\text { Post-test } \\
\text { probability }(\%)^{\mathrm{b}}\end{array}$ \\
\hline Taller than wide & 26.7 & 96.6 & 8.07 & 47.0 & 0.75 & 7.6 \\
\hline Halo absent & 56.4 & 72.0 & 2.02 & 18.1 & 0.60 & 6.2 \\
\hline Absence of elasticity & 87.9 & 86.2 & 6.39 & 41.3 & 0.13 & 1.4 \\
\hline Heterogeneity & 47.5 & 70.0 & 1.58 & 14.8 & 0.74 & 7.5 \\
\hline Hypoechogenicity & 62.7 & 62.3 & 1.66 & 15.4 & 0.62 & 6.3 \\
\hline Solid & 72.7 & 53.2 & 1.55 & 14.6 & 0.51 & 5.3 \\
\hline Microcalcifications & 39.5 & 87.8 & 3.26 & 26.4 & 0.68 & 7.0 \\
\hline Solitary & 53.0 & 60.2 & 1.33 & 12.8 & 0.77 & 7.8 \\
\hline Central vascularization & 45.9 & 78.0 & 2.09 & 18.7 & 0.69 & 7.1 \\
\hline Irregular margins & 50.5 & 83.1 & 2.99 & 24.7 & 0.59 & 6.1 \\
\hline
\end{tabular}

\footnotetext{
${ }^{a}$ Probability of malignancy after having a positive test result.
}

${ }^{\mathrm{b}}$ Probability of malignancy after having a negative test result. 
Hypoechogenicity

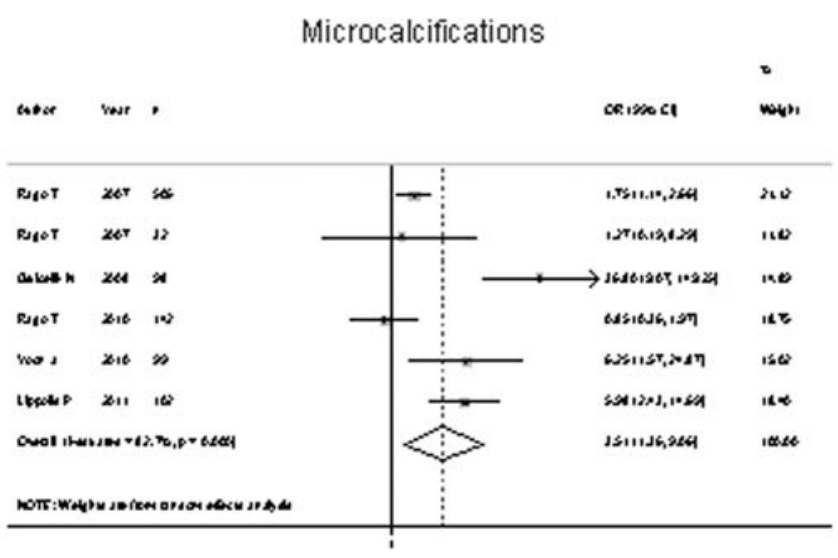

Absence of elasticity

\section{Central vascularization}

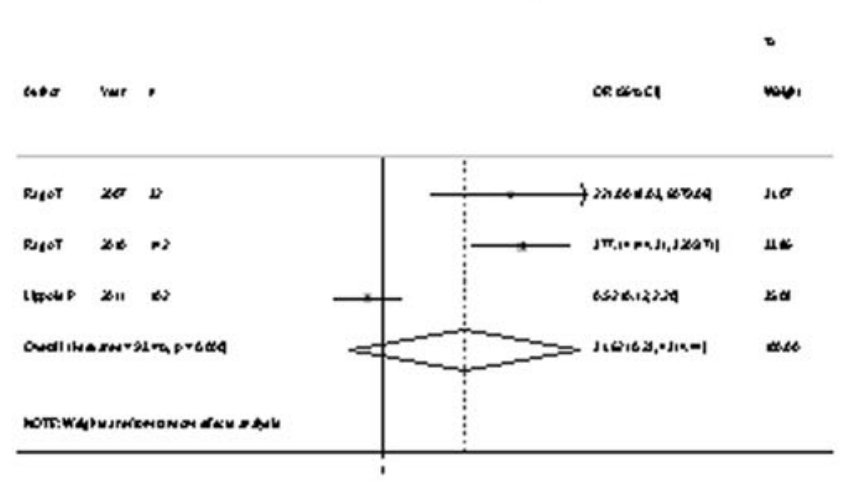

$$
\text { Irregular margins }
$$
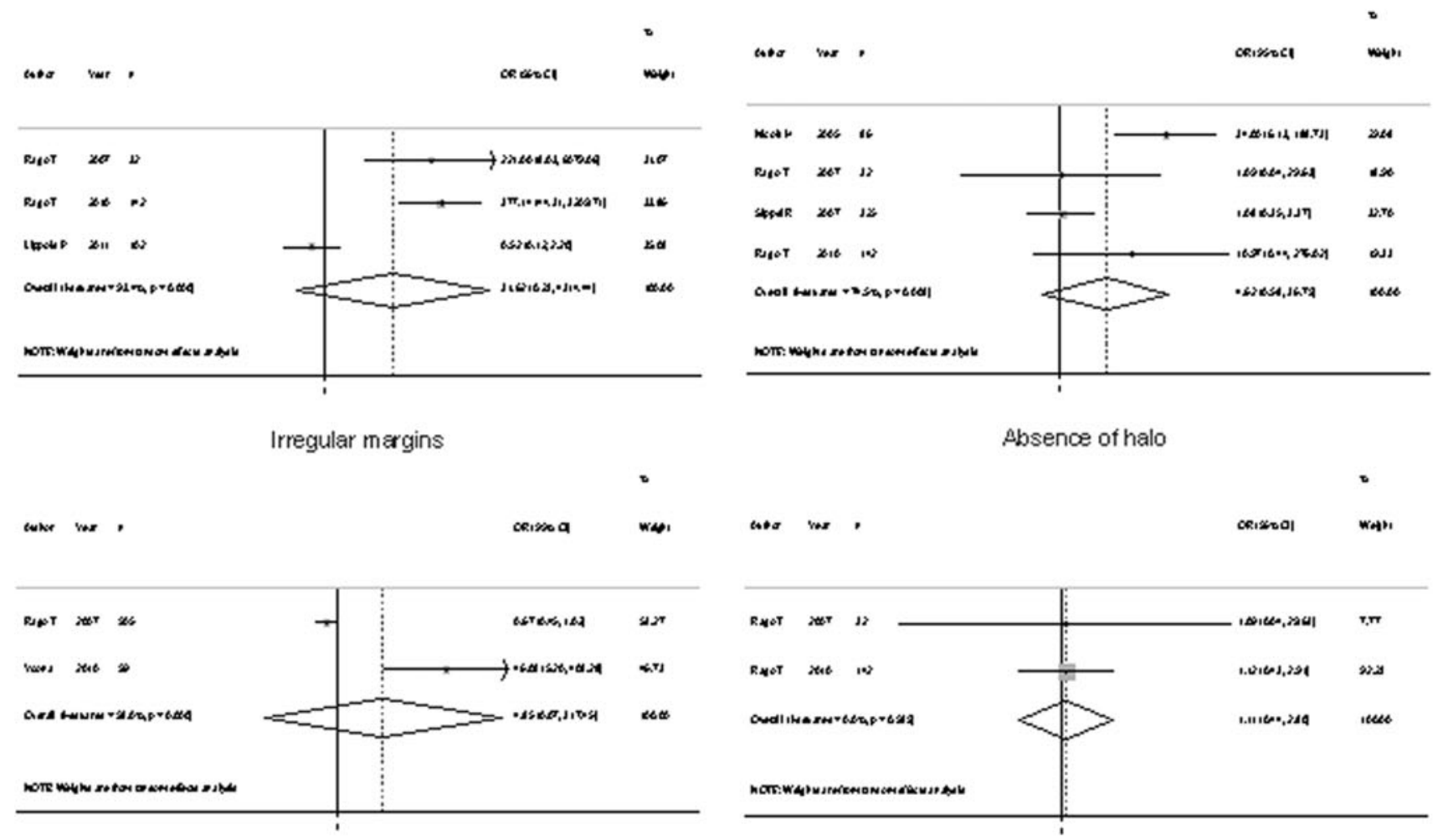

Being solid
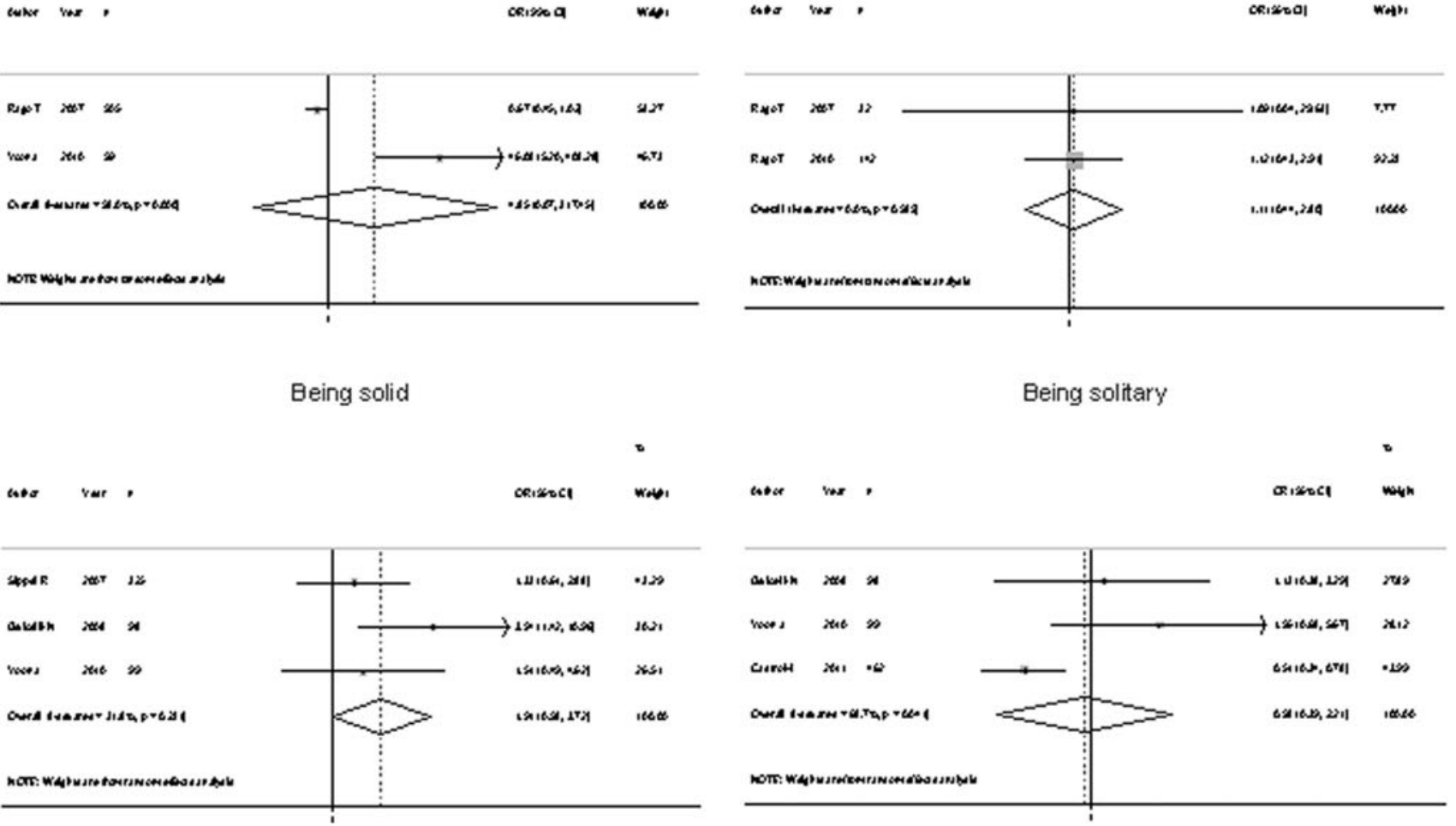

Being solitary

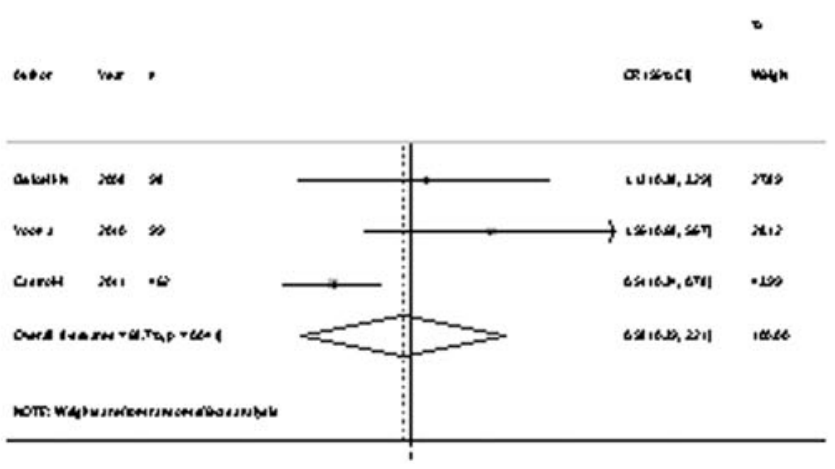

FIG. 3. Forest plot representing OR for malignancy of each US feature evaluated in nodules with indeterminate cytology. 
Table 3. Diagnostic Performance of Each US Feature in the Differentiation of Benign and Malignant Thyroid Nodules in Nodules with Indeterminate Cytology

\begin{tabular}{lcccccc}
\hline Criterion & $\begin{array}{c}\text { Sensitivity } \\
(\%)\end{array}$ & $\begin{array}{c}\text { Specificity } \\
(\%)\end{array}$ & $\begin{array}{c}\text { Positive } \\
\text { likelihood ratio }\end{array}$ & $\begin{array}{c}\text { Post-test } \\
\text { probability }(\%)^{\mathrm{a}}\end{array}$ & $\begin{array}{c}\text { Negative } \\
\text { likelihood ratio }\end{array}$ & $\begin{array}{c}\text { Post-test } \\
\text { probability }(\%)^{\mathrm{b}}\end{array}$ \\
\hline Hypoechogenicity & 49.7 & 56.0 & 1.12 & 11.0 & 0.89 & 8.9 \\
Microcalcifications & 45.6 & 81.9 & 2.52 & 21.8 & 0.66 & 6.8 \\
Central vascularization & 8.4 & 96.0 & 2.13 & 19.1 & 0.95 & 9.5 \\
\hline
\end{tabular}

${ }^{a}$ Probability of malignancy after having a positive test result.

${ }^{\mathrm{b}}$ Probability of malignancy after having a negative test result.

positive likelihood ratio ranged from 1.12 to 2.52 , and the negative likelihood ratio from 0.66 to 0.95 . Considering a pretest probability of $10 \%$, the post-test probability of malignancy ranged from $11 \%$ to $21.8 \%$ after a positive test, and $6.8 \%$ to $9.5 \%$ with a negative test result.

\section{Meta-regression}

In the analysis of some features, fewer than 10 studies were available, preventing a meta-regression from being performed. For analysis of hypoechogenicity, irregular margins, microcalcifications, solid structure, and central vascularization, a meta-regression was performed using the year of publication and/or the prevalence of cancer in the study sample as covariates. However, none of these variables was able to explain the high heterogeneity found significantly.

\section{Discussion}

In the present meta-analysis, the US features associated with a higher risk and post-test probability of malignancy were taller than wide shape, absence of elasticity, presence of microcalcifications, and irregular margins. However, none of the US features analyzed singly had a clinically relevant positive likelihood ratio $(>10)$ and post-test probabilities to suggest malignancy. Most likely, the use in combination may provide stronger risk and probability of malignancy. However, it was not possible to estimate the real risk of malignancy by using the combination of US features because very few studies have analyzed this aspect, and they differ regarding the selected features.

The strengths of the presents meta-analysis are the large number of nodules evaluated and the fact that all the nodules included had a histopathologic diagnosis, which is the reference method for the definite diagnosis of thyroid nodules. Moreover, the performance of US in nodules with indeterminate cytology was also analyzed, which constitutes the most challenging group of patients for clinical decision making. Another relevant aspect was the calculation of the likelihood ratio statistics, which summarizes how many times more (or less) likely patients with the disease are to have that particular result than patients without the disease (14). The likelihood ratio of a diagnostic test is more useful clinically than sensitivity and specificity. To the best of the authors' knowledge, there are no previous systematic reviews and meta-analyses that focus on histopathology only.

The present study has some limitations. First, no information was available on individual characteristics of patients regarding risk factors for malignancy, and on the reason for surgery. Also, the number of studies was insufficient for the analysis of some US features in patients with indeterminate cytology, possibly the subgroup of patients that would most benefit from the use of US as a tool to help in clinical management decision.

Our results confirm the findings of previous isolated studies. Moon et al. (69) evaluated 831 patients with thyroid nodules and found low sensitivity values for most of the US features. Hypoechogenicity was the only finding that showed a sensitivity of $87.2 \%$. In the same study, taller than wide shape, speculated margins, marked hypoechogenicity, and micro- and macrocalcifications demonstrated a high specificity for malignancy, ranging from $90.8 \%$ to $96.1 \%$. In one of the largest series comprising 672 patients and 1141 nodules, Popovicz et al. also found low sensitivity values for most US features for malignancy. However, microcalcifications and taller than wide shape features had high specificity (50). Moreover, in another study including 550 patients with multinodular goiter, Salmaslioglu et al. found that the presence of microcalcifications had a sensitivity of $89.3 \%$ for malignancy (57). The best diagnostic performance in the present meta-analysis was seen for absence of elasticity. Usually, elasticity is described in a scale ranging from 1 to 4 (1-2 being suggestive of a benign nodule and 3-4 of malignancy) or 1-5 (where 1-3 is suggestive of a benign lesion and 4-5 of malignancy) (53,70-72). This US feature was initially described for breast or prostate cancer, but several studies have evaluated its performance to differentiate between malignant and benign thyroid nodules, revealing high sensitivity and specificity (81.8-97\% and 81.1-100\%) (52,72). A recent meta-analysis including eight studies with a total of 639 nodules diagnosed by FNA cytopathology or histopathology reported a sensitivity of $90 \%$ and specificity of $92 \%$ for elasticity. However, not all studies included had a final histopathologic diagnosis of the nodule (70). A recent study, which included 498 thyroid nodules evaluated by US, color flux Doppler, and real-time elastography, concluded that the combination of elastography with US parameters increased the sensitivity for malignancy to $97 \%$ (73).

The present findings have important clinical implications. They reinforce that isolated US features on their own do not provide strong evidence to confirm (likelihood ratio $>10$ ) or rule out (likelihood ratio $<0.1$ ) a diagnosis of malignancy. The American Thyroid Association recommends the use of a combination of US features to select thyroid nodules that should be biopsied (5). Information about the probability of each US feature to be associated with malignancy would help the clinical decision to perform FNA biopsy. 
The present findings also suggest that more accurate criteria are needed to recommend surgery in patients with indeterminate cytology. This is an important practical matter, since it would be helpful to select better which patients should be submitted to FNA and, specially, when surgery should be indicated in those nodules with indeterminate cytology $(74,75)$.

Attempts have been made to improve patient selection in evaluation of thyroid nodules. Moon et al. evaluated a classification that considered as suspicious for malignancy a nodule that was solid plus having two additional risk features. Those authors found a sensitivity of $87.7 \%$, a specificity of $97.8 \%$, and an overall accuracy of $96.2 \%$ (76). A recent, retrospective case-control study of patients who underwent thyroid US reported three ultrasound nodule characteristics (microcalcifications, size $>2 \mathrm{~cm}$, and an entirely solid composition) as the only findings associated with the risk of thyroid cancer (77). However, this study has important aspects that limit its generalization such as the low prevalence of thyroid cancer and the definition of noncancerous nodules (78).

\section{Conclusions}

The present results show that there is no isolated US feature capable of predicting malignancy in thyroid nodules with acceptable diagnostic accuracy. However, the presence of some US features, such as a microcalcifications, a taller than wide shape, irregular margins, central vascularization, or absence of elasticity probably, will identify nodules with an increased risk for malignancy. Ideally, meta-analyses should be performed with individual patient data, which would enable the creation of a risk classification for malignancy in thyroid nodules considering US features in combination and other risk factors to define better which patients should be submitted to FNA and surgery. Elastography is a new technique and may be a good tool to select patients at increased risk for thyroid malignancy. Nevertheless, more studies are required to standardize the technique and confirm its usefulness.

\section{Acknowledgment}

J.L.G. holds a grant from Conselho Nacional de Desenvolvimento Científico e Tecnológico (CNPq)-project 558637/2008-6.

\section{Author Disclosure Statement}

All authors have completed the Unified Competing Interest form at www.icmje.org/coi_disclosure.pdf (available on request from the corresponding author) and declare that they have no competing interests relevant to this work. J.L.G. has served on boards for Bristol-Myers Squibb, GlaxoSmithKline, Novo Nordisk, and Eli Lilly, and has received payment for the development of educational presentations for BristolMyers Squibb, Novo Nordisk, and Eli Lilly.

\section{References}

1. Brander A, Viikinkoski P, Nickels J, Kivisaari L 1991 Thyroid gland: US screening in a random adult population. Radiology 181:683-687.
2. Ezzat S, Sarti DA, Cain DR, Braunstein GD 1994 Thyroid incidentalomas. Prevalence by palpation and ultrasonography. Arch Intern Med 154:1838-1840.

3. Dean DS, Gharib H 2008 Epidemiology of thyroid nodules. Best Pract Res Clin Endocrinol Metab 22:901-911.

4. Hegedus L 2004 Clinical practice. The thyroid nodule. N Engl J Med 351:1764-1771.

5. Cooper DS, Doherty GM, Haugen BR, Kloos RT, Lee SL, Mandel SJ, Mazzaferri EL, McIver B, Pacini F, Schlumberger M, Sherman SI, Steward DL, Tuttle RM 2009 Revised American Thyroid Association management guidelines for patients with thyroid nodules and differentiated thyroid cancer. Thyroid 19:1167-1214.

6. Werk EE Jr, Vernon BM, Gonzalez JJ, Ungaro PC, McCoy RC 1984 Cancer in thyroid nodules. A community hospital survey. Arch Intern Med 144:474-476.

7. Frates MC, Benson CB, Doubilet PM, Kunreuther E, Contreras M, Cibas ES, Orcutt J, Moore FD, Jr., Larsen PR, Marqusee E, Alexander EK 2006 Prevalence and distribution of carcinoma in patients with solitary and multiple thyroid nodules on sonography. J Clin Endocrinol Metab 91:3411-3417.

8. Jin J, McHenry CR 2012 Thyroid incidentaloma. Best Pract Res Clin Endocrinol Metab 26:83-96.

9. Brito JP, Morris JC, Montori VM 2013 Thyroid cancer: zealous imaging has increased detection and treatment of low risk tumours. BMJ 347:f4706.

10. Frates MC, Benson CB, Charboneau JW, Cibas ES, Clark $\mathrm{OH}$, Coleman BG, Cronan JJ, Doubilet PM, Evans DB, Goellner JR, Hay ID, Hertzberg BS, Intenzo CM, Jeffrey RB, Langer JE, Larsen PR, Mandel SJ, Middleton WD, Reading CC, Sherman SI, Tessler FN 2005 Management of thyroid nodules detected at US: Society of Radiologists in Ultrasound consensus conference statement. Radiology 237:794-800.

11. Rago T, Vitti P 2008 Role of thyroid ultrasound in the diagnostic evaluation of thyroid nodules. Best Pract Res Clin Endocrinol Metab 22:913-928.

12. Bojunga J, Herrmann E, Meyer G, Weber S, Zeuzem S, Friedrich-Rust M 2010 Real-time elastography for the differentiation of benign and malignant thyroid nodules: a meta-analysis. Thyroid 20:1145-1150.

13. Brito JP, Gionfriddo MR, Al Nofal A, Boehmer KR, Leppin AL, Reading C, Callstrom M, Elraiyah TA, Prokop LJ, Stan MN, Murad H, Morris JC, Montori VM 2014 The accuracy of thyroid nodule ultrasound to predict thyroid cancer: systematic review and meta-analysis. J Clin Endocrinol Metab 99:1253-1263.

14. Deeks JJ, Altman DG 2004 Diagnostic tests 4: likelihood ratios. BMJ 329:168-169.

15. Whiting PF, Rutjes AW, Westwood ME, Mallett S, Deeks JJ, Reitsma JB, Leeflang MM, Sterne JA, Bossuyt PM 2011 QUADAS-2: a revised tool for the quality assessment of diagnostic accuracy studies. Ann Intern Med 155:529-536.

16. Stroup DF, Berlin JA, Morton SC et al., 2000 Meta-analysis of observational studies in epidemiology. A proposal for reporting. JAMA 283:2008-2012.

17. Aggarwal SK, Jayaram G, Kakar A, Goel GD, Prakash R, Pant CS 1989 Fine needle aspiration cytologic diagnosis of the solitary cold thyroid nodule. Comparison with ultrasonography, radionuclide perfusion study and xeroradiography. Acta Cytol 33:41-47.

18. Alexopoulou O, Beguin C, Buysschaert M, Squifflet JP, De Burbure C, De Nayer P, Daumerie C 2004 Predictive 
factors of thyroid carcinoma in non-toxic multinodular goitre. Acta Clin Bel 59:84-89.

19. Bakhshaee M, Davoudi Y, Mehrabi M, Layegh P, Mirsadaee S, Rad MP, Leyegh P 2008 Vascular pattern and spectral parameters of power Doppler ultrasound as predictors of malignancy risk in thyroid nodules. Laryngoscope 118:2182-2186.

20. Bozbora A, Erbil Y, Ozarmagan S, Barbaros U, Sari S, Degirmenci B 2002 Color Doppler sonography in cold thyroid nodules for malignancy prediction. Acta Chir Belg 102:259-262.

21. Brkljacic B, Cuk V, Tomic-Brzac H, Bence-Zigman Z, Delic-Brkljacic D, Drinkovic I 1994 Ultrasonic evaluation of benign and malignant nodules in echographically multinodular thyroids. J Clin Ultrasound 22:71-76.

22. Cakir B, Aydin C, Korukluoglu B, Ozdemir D, Sisman IC, Tuzun D, Oguz A, Guler G, Guney G, Kusdemir A, Yavuz Sanisoglu S, Ersoy R 2011 Diagnostic value of elastosonographically determined strain index in the differential diagnosis of benign and malignant thyroid nodules. Endocrine 39:89-98.

23. Cantisani V, D'Andrea V, Biancari F, Medvedyeva O, Di Segni M, Olive M, Patrizi G, Redler A, De Antoni EE, Masciangelo R, Frezzotti F, Ricci P 2012 Prospective evaluation of multiparametric ultrasound and quantitative elastosonography in the differential diagnosis of benign and malignant thyroid nodules: preliminary experience. Eur J Radiol 81:2678-2683.

24. Cappelli C, Castellano M, Pirola I, Cumetti D, Agosti B, Gandossi E, Agabiti Rosei E 2007 The predictive value of ultrasound findings in the management of thyroid nodules. QJM 100:29-35.

25. Casella C, Talarico C, La Pinta M, Nascimbeni R, Di Fabio F, Salerni B 2003 The role of color flow-Doppler ultrasonography in the diagnosis of nodular goiter. Ann Ital Chir 74:495-499.

26. Castro MR, Espiritu RP, Bahn RS, Henry MR, Gharib H, Caraballo PJ, Morris JC Predictors of malignancy in patients with cytologically suspicious thyroid nodules. Thyroid 21:1191-1198.

27. Chen G, Zhu XQ, Zou X, Yao J, Liang JX, Huang HB, Li LT, Lin LX 2009 Retrospective analysis of thyroid nodules by clinical and pathological characteristics, and ultrasonographically detected calcification correlated to thyroid carcinoma in South China. Eur Surg Res 42:137142.

28. Choi YJ, Kim SM, Choi Sin 2008 Diagnostic accuracy of ultrasound features in thyroid microcarcinomas. Endocr $\mathrm{J}$ 55:931-938.

29. Cox MR, Marshall SG, Spence RAJ 1991 Solitary thyroid nodule: a prospective evaluation of nuclear scanning and ultrasonography. Br J Surg 78:90-93.

30. De Nicola H, Szejnfeld J, Logullo AF, Wolosker AMB, Souza LRMF, Chiferi Jr V 2005 Flow pattern and vascular resistive index as predictors of malignancy risk in thyroid follicular neoplasms. J Ultrasound Med 24:897-904.

31. Fukunari N, Nagahama M, Sugino K, Mimura T, Ito K 2004 Clinical evaluation of color Doppler imaging for the differential diagnosis of thyroid follicular lesions. World $\mathbf{J}$ Surg 28:1261-1265.

32. Ghervan CMV, Dumitriu D, Botar-Jid C, Dudea SM, Muntean V, Duncea IM 2011 Ultrasound elastography a valuable method to exclude thyroid malignancy. Endocr Rev 32:P1-702.
33. Giammanco M, Di Gesu G, Massenti MF, Di Trapani B, Vetri G 2002 Role of color flow Doppler sonography in pre-operative diagnostics of the thyroid pathology. Minerva Endocrinol 27:1-10.

34. Gulcelik NE, Gulcelik MA, Kuru B 2008 Risk of malignancy in patients with follicular neoplasm: predictive value of clinical and ultrasonographic features. Arch Otolaryngol Head Neck Surg 134:1312-1315.

35. Hong Y, Liu X, Li Z, Zhang X, Chen M, Luo Z 2009 Realtime ultrasound elastography in the differential diagnosis of benign and malignant thyroid nodules. J Ultrasound Med 28:861-867.

36. Hubsch P, Niederle B, Barton P, Pesau B, Knittel M, Schratter M, Hermann M, Langle F 1992 Color-coded Doppler sonography of the thyroid: an advance in carcinoma diagnosis? Rofo 156:125-129.

37. Kakkos SK, Scopa CD, Chalmoukis AK, Karachalios DA, Spiliotis JD, Harkoftakis JG, Karavias DD, Androulakis JA, Vagenakis AG 2000 Relative risk of cancer in sonographically detected thyroid nodules with calcifications. J Clin Ultrasound 28:347-352.

38. Khoo ML, Asa SL, Witterick IJ, Freeman JL 2002 Thyroid calcification and its association with thyroid carcinoma. Head Neck 24:651-655.

39. Kobayashi K, Fukata S, Miyauchi A 2005 Diagnosis of follicular carcinoma of the thyroid: role of sonography in preoperative diagnosis of follicular nodules. J Med Ultrasonics 32:153-158.

40. Kountakis SE, Skoulas IG, Maillard AAJ 2002 The radiologic work-up in thyroid surgery: fine-needle biopsy versus scintigraphy and ultrasound. Ear Nose Throat J 81:151-154.

41. Leenhardt L, Menegaux F, Franc B, Delbot T, Mansour G, Hoang C, Guillausseau C, Aurengo H, Le Guillouzic D, Turpin G, Aurengo A, Chigot JP, Hejblum G 2002 Selection of patients with solitary thyroid nodules for operation. Eur J Surg 168:236-241.

42. Lippolis PV, Tognini S, Materazzi G, Polini A, Mancini R, Ambrosini CE, Dardano A, Basolo F, Seccia M, Miccoli P, Monzani F 2011 Is elastography actually useful in the presurgical selection of thyroid nodules with indeterminate cytology? J Clin Endocrinol Metab 96:E1826E1830.

43. Liu FH, Hsueh C, Chang HY, Liou MJ, Huang BY, Lin JD 2009 Sonography and fine-needle aspiration biopsy in the diagnosis of benign versus malignant nodules in patients with autoimmune thyroiditis. J Clin Ultrasound 37:487492.

44. Maia FFR, Matos PS, Silva BP, Pallone AT, Pavin EJ, Vassallo J, Zantut-Wittmann DE 2011 Role of ultrasound, clinical and scintigraphyc parameters to predict malignancy in thyroid nodule. Head Neck Oncol 3:17.

45. Mendelson AA, Tamilia M, Rivera J, Hier MP, Sherman M, Garfield N, Black MJ, Rochon L, Gologan O, Payne RJ 2009 Predictors of malignancy in preoperative nondiagnostic biopsies of the thyroid. J Otolaryngol Head Neck Surg 38:395-400.

46. Ousehal A, Abdelouafi A, Essodegui F, Ouzidane L, Moumen M, Kadiri R 1996 Contribution of ultrasonography in thyroid diseases. Apropos of 100 cases. Ann Radiol (Paris) 39:146-152.

47. Peccin S, De Castro JAS, Furlanetto TW, Furtado APA, Brasil BA, Czepielewski MA 2002 Ultrasonography: is it useful in the diagnosis of cancer in thyroid nodules? $\mathrm{J}$ Endocrinol Invest 25:39-43. 
48. Penfold A, Vargas Perez C, Chipolla A, Civeriatti O, Macagno G, Lopez Vinuesa F, Jalil N, Rey O 2004 The ultrasonography of high resolution and color Doppler in the nodular pathology thyroid:pathologicanatomic correlation. Rev Argentina Endocrinol Metab 41:131-142.

49. Phuttharak W, Somboonporn C, Hongdomnern G 2009 Diagnostic performance of gray-scale versus combined gray-scale with colour Doppler ultrasonography in the diagnosis of malignancy in thyroid nodules. Asian Pac J Cancer Prev 10:759-764.

50. Popowicz B, Klencki M, Lewinski A, Slowinska-Klencka D 2009 The usefulness of sonographic features in selection of thyroid nodules for biopsy in relation to the nodule's size. Eur J Endocrinol 161:103-111.

51. Popowicz B, Slowinska-Klencka D, Sporny S, Klencki M, Lewinski A 2006 Small lesions of the thyroid gland-the significance of ultrasound examination in the selection of lesions for biopsy. Endokrynol Pol 57:292-298.

52. Rago T, Di Coscio G, Basolo F, Scutari M, Elisei R, Berti P, Miccoli P, Romani R, Faviana P, Pinchera A, Vitti P 2007 Combined clinical, thyroid ultrasound and cytological features help to predict thyroid malignancy in follicular and Hürthle cell thyroid lesions: results from a series of 505 consecutive patients. Clin Endocrinol (Oxf) 66:13-20.

53. Rago T, Santini F, Scutari M, Pinchera A, Vitti P 2007 Elastography: new developments in ultrasound for predicting malignancy in thyroid nodules. J Clin Endocrinol Metab 92:2917-2922.

54. Rago T, Scutari M, Santini F, Loiacono V, Piaggi P, Di Coscio G, Basolo F, Berti P, Pinchera A, Vitti P 2010 Realtime elastosonography: useful tool for refining the presurgical diagnosis in thyroid nodules with indeterminate or nondiagnostic cytology. J Clin Endocrinol Metab 95:52745280.

55. Rago T, Vitti P, Chiovato L, Mazzeo S, De Liperi A, Miccoli P, Viacava P, Bogazzi F, Martino E, Pinchera A 1998 Role of conventional ultrasonography and color flowDoppler sonography in predicting malignancy in "cold" thyroid nodules. Eur J Endocrinol 138:41-46.

56. Sahin M, Sengul A, Berki Z, Tutuncu NB, Guvener ND 2006 Ultrasound-guided fine-needle aspiration biopsy and ultrasonographic features of infracentimetric nodules in patients with nodular goiter: Correlation with pathological findings. Endocr Pathol 17:67-74.

57. Salmaslioglu A, Erbil Y, Dural C, Issever H, Kapran Y, Ozarmagan S, Tezelman S 2008 Predictive value of sonographic features in preoperative evaluation of malignant thyroid nodules in a multinodular goiter. World J Surg 32:1948-1954.

58. Schueller-Weidekamm C, Schueller G, Kaserer K, Scheuba C, Ringl H, Weber M, Czerny C, Herneth AM 2010 Diagnostic value of sonography, ultrasound-guided fineneedle aspiration cytology, and diffusion-weighted MRI in the characterization of cold thyroid nodules. Eur J Radiol 73:538-544.

59. Seiberling KA, Dutra JC, Grant T, Bajramovic S 2004 Role of intrathyroidal calcifications detected on ultrasound as a marker of malignancy. Laryngoscope 114: 1753-1757.

60. Sharma R, Chakravarty KL, Tripathi M, Kaushik A, Bharti P, Sahoo M, Chopra MK, Rawat H, Misra A, Mondal A, Kashyap R 2007 Role of 99mTc-Tetrofosmin delayed scintigraphy and color Doppler sonography in characterization of solitary thyroid nodules. Nucl Med Commun 28:847-851.

61. Shuzhen C 2012 Comparison analysis between conventional ultrasonography and ultrasound elastography of thyroid nodules. Eur J Radiol 81:1806-1811.

62. Sillery JC, Reading CC, Charboneau JW, Henrichsen TL, Hay ID, Mandrekar JN 2010 Thyroid follicular carcinoma: sonographic features of 50 cases. Am J Roentgenol 194:44-54.

63. Sippel RS, Elaraj DM, Khanafshar E, Kebebew E, Duh QY, Clark OH 2007 Does the presence of additional thyroid nodules on ultrasound alter the risk of malignancy in patients with a follicular neoplasm of the thyroid? Surgery 142:851-857.

64. Varverakis E, Neonakis E, Tzardi M, Chrysos E 2007 Role of color Doppler ultrasonography in the preoperative management of cold thyroid nodules. Hormones (Athens) 6:44-51.

65. Walker J, Findlay D, Amar SS 1985 A prospective study of thyroid ultrasound scan in the clinically solitary thyroid nodule. Br J Radiol 58:617-619.

66. Wang N, Xu Y, Ge C, Guo R, Guo K 2006 Association of sonographically detected calcification with thyroid carcinoma. Head Neck 28:1077-1083.

67. Wang Y, Dan HJ, Dan HY, Li T, Hu B 2010 Differential diagnosis of small single solid thyroid nodules using real-time ultrasound elastography. J Int Med Res 38:466-472.

68. Yoon JH, Kwak JY, Kim EK, Moon HJ, Kim MJ, Kim JY, Koo HR, Kim MH 2010 How to approach thyroid nodules with indeterminate cytology. Ann Surg Oncol 17:21472155.

69. Moon WJ, Jung SL, Lee JH, Na DG, Baek JH, Lee YH, Kim J, Kim HS, Byun JS, Lee DH 2008 Benign and malignant thyroid nodules: US differentiation-multicenter retrospective study. Radiology 247:762-770.

70. Bojunga J, Herrmann E, Meyer G, Weber S, Zeuzem S, Friedrich-Rust M 2010 Real-time elastography for the differentiation of benign and malignant thyroid nodules: a meta-analysis. Thyroid 20:1145-1150.

71. Ueno E, Ito A 2004 Diagnosis of breast cancer by elasticity imaging. Eizo Joho Medical 36:2-6.

72. Asteria C, Giovanardi A, Pizzocaro A, Cozzaglio L, Morabito A, Somalvico F, Zoppo A 2008 US-elastography in the differential diagnosis of benign and malignant thyroid nodules. Thyroid 18:523-531.

73. Trimboli P, Guglielmi R, Monti S, Misischi I, Graziano F, Nasrollah N, Amendola S, Morgante SN, Deiana MG, Valabrega S, Toscano V, Papini E 2012 Ultrasound sensitivity for thyroid malignancy is increased by real-time elastography: a prospective multicenter study. J Clin Endocrinol Metab 97:4524-4530.

74. Mehanna HM, Jain A, Morton RP, Watkinson J, Shaha A 2009 Investigating the thyroid nodule. BMJ 338:b733.

75. Langer JE, Baloch ZW, McGrath C, Loevner LA, Mandel SJ 2012 Thyroid nodule fine-needle aspiration. Semin Ultrasound CT MR 33:158-165.

76. Moon HG, Jung EJ, Park ST, Ha WS, Choi SK, Hong SC, Lee YJ, Joo YT, Jeong CY, Choi DS, Ryoo JW 2007 Role of ultrasonography in predicting malignancy in patients with thyroid nodules. World J Surg 31:1410-1416.

77. Smith-Bindman R1, Lebda P, Feldstein VA, Sellami D, Goldstein RB, Brasic N, Jin C, Kornak J 2013 Risk of 
thyroid cancer based on thyroid ultrasound imaging characteristics: results of a population-based study. JAMA Intern Med 173:1788-1796.

78. Gross JL, Kramer CK, Remonti LR 2014 Clinical decision making in patients with thyroid nodules: letter to the editor-comment on Smith-Bindman et al. "Risk of thyroid cancer based on thyroid ultrasound imaging characteristics. Results of a population-based study." JAMA Intern Med 174:1005-1006.

79. Nikiforov YE, Ohori NP, Hodak SP, Carty SE, LeBeau SO, Ferris RL, Yip L, Seethala RR, Tublin ME, Stang MT, Coyne C, Johnson JT, Stewart AF, Nikiforova MN 2011 Impact of mutational testing on the diagnosis and management of patients with cytologically indeterminate thyroid nodules: a prospective analysis of 1056 FNA samples. J Clin Endocrinol Metab 96:33903397.

Address correspondence to: Luciana Reck Remonti, MD Hospital de Clínicas de Porto Alegre Ramiro Barcelos 2350 Porto Alegre, RS Brazil

E-mail: lucianalreck@gmail.com 